\title{
Fuera del canon de la Legenda aurea: la vida de san Antolín en los Flores sanctorum castellano medievales
}

Recibido: 3/3/2016

Aceptado: 13/6/2016

\section{RESUMEN:}

Entre las leyendas hagiográficas, la de san Antolín ocupa un lugar singular. Calificada como prosa fabulosa y vida fabulosísima por fuentes y autoridades del género; despreciada por Santiago de la Vorágine en su Legenda aurea, esta narración disfrutó de una gran difusión en los santorales manuscritos medievales castellanos que integran las llamadas Compilación A y la Compilación B. Esta popularidad continuó en los primeros tiempos de la imprenta y, en el Flos sanctorum con sus ethimologías, uno de los primeros incunables de la Península Ibérica, encontramos una ambiciosa versión de la leyenda.

PALABRAS CLAVE: hagiografía, flos sanctorum, san Antolín, Compilación B, incunable.

Outside the canon of the Golden Legend: the life of Saint Antolín in the Medieval Castilian Flores sanctorum

\section{ABSTRACT:}

Among the hagiographical legends, the life of Saint Antolin has a special place. Qualified by sources of this gender as fantastic prose and fictitious life, ignored by Iacopo da Varazze in his Legenda aurea, this narration had a wide circulation among the Spanish medieval manuscripts about the life of saints, consisting of the so called Compilation $A$ and Compilation B. This popularity continued until the beginning of the printing revolution and we can find a longer and more detailed 
version of the legend in one of the first incunabulum of the Iberian Peninsula: Flos sanctorum con sus ethimologías.

KEY WORDS: Key words: hagiography, flos sanctorum, Antolin, Compilation B, incunabulum.

En los santorales manuscritos castellanos que han llegado hasta nuestros días existe una intrincada filiación que mantiene una deuda con la Legenda aurea ${ }^{1}$. Sin embargo, los copistas de estos flores sanctorum no sólo tuvieron esta fuente frente a ellos, sino que, además -quizá movidos por una devoción local- no dudaron al momento de añadir algunas vidas de santos procedentes de otras fuentes textuales. Aunque minoritario en comparación con el listado de vidas de santos provenientes de la compilación de Santiago de la Vorágine ${ }^{2}$, este añadido es uno de los rasgos más notables a la hora de acentuar las peculiaridades que existen entre cada uno de estos santorales pretridentinos. Y este hecho de la tradición manuscrita medieval es una herencia para uno de los primeros incunables de la Península Ibérica, me refiero al Flos sanctorum con sus ethimologías, joya en bruto de los santorales castellanos impresos.

Este raro incunable que hoy descansa en la biblioteca del Congreso de Washington (Incun x/7.59) ha pasado del olvido, con apenas un puñado de artículos consagrados a presentarlo ante el mundo académico ${ }^{3}$, a contar con una edición y estudio que ha intentado resolver cada uno de las incógnitas que plantea ${ }^{4}$. No

1 Esto puede afirmarse tras el estudio realizado por Hernández Amez (2008).

2 Compilación sabiamente editada por Giovanni Paolo Maggioni (1998).

3 Aragüés Aldaz, Baños Vallejo, Fernández Rodríguez y Hernández Amez fueron los responsables de rescatar esta obra del olvido, sus resultados pueden consultarse en las Actas del XI Congreso Internacional de la Asociación Hispánica de Literatura Medieval, celebrado en León, en el año 2007.

4 Este fue el propósito de mi tesis doctoral. Puede consultarse a través del portal de la Biblioteca Virtual Miguel de Cervantes: www.cervantesvirtual.com 
obstante, aún con este esfuerzo, por los casi ochocientos folios que integran este santoral se esconden muchas maravillas que todavía quedan por ser descubiertas, tal como el caso que aquí se presenta. En efecto, la vida de san Antolín merece una atención especial, pues no sólo es el texto más extenso que no procede de Vorágine $^{5}$, sino que, además, es el caso de una vida de santo donde lo milagroso llega a niveles de lo fabuloso ${ }^{6}$, hecho que llama la atención al considerar la gran aceptación y acogida que tuvo en varios Flores sanctorum que integran el panorama prosístico de la literatura hagiográfica castellana medieval.

\section{La leyenda de san Antolín}

Estamos ante el patrón de los cazadores, patrón de la ciudades de Palencia y de Medina del Campo y referencia común en topónimos dispersos por España y Latinoamérica. Atributos de considerable importancia si consideramos las Acta Sanctorum $^{7}$, las cuales refieren que san Antolín es un santo que tiene en su acervo algunos documentos calificados de "prorsus

5 Los otros son: dos vidas de santos, la vida de santo Toribio y la vida de san Julián y santa Basilisa; un breve exemplum, el cual tiene por tema el Oficio del lunes de difuntos; un texto doctrinal; y una tabla de contenidos comentada. Para un estudio detallado de estos dos últimos textos véase Cortés Guadarrama (2010: 117-128; y 2011: 583-598).

6 Lo fabuloso no difiere de lo maravilloso cristiano ni de lo milagroso, pues en todos estos casos hay un único autor de lo no explicable en el mundo verificable: Dios. Sin embargo, Le Goff señala que "precisamente aquí es donde se plantea el problema del puesto de lo maravilloso, no solo en una religión, sino en una religión monoteísta [...] hay una reglamentación de lo maravilloso en el milagro" (2008: 15). Sin entrar aquí en controversias entre las posibles definiciones de las categorías narrativas de lo maravilloso, lo fantástico, lo extraordinario, etc., explicadas por autores como Todorov (2006) o Botton Burlá (1994) en el presente artículo se asume como prosa hagiográfica fabulosa a un texto saturado de esta reglamentación de lo maravilloso propio del discurso cristiano.

7 Acta Sanctorum, en http://acta.chadwyck.co.uk, pp. 340-356. 
fabulosa"8. Por ello, es conveniente un breve repaso de las características más relevantes de esta leyenda hagiográfica.

La vida de este santo se extrae de diversas fuentes: unas actas anónimas, tomadas de un códice (núm. 33) que perteneció a la reina de Suecia, y otros textos del siglo XIII del Speculum

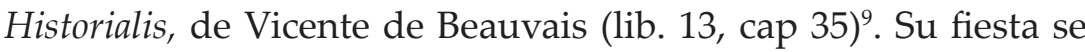
celebra el 2 de septiembre y hay presencia de su culto desde el siglo VI en Apamea, Siria; posteriormente, en Pamia ciudad de la Galia (hoy Pamiers, Francia) y, por supuesto, en la Palencia de la Hispania visigoda. Tal distribución geográfica quizá haya contribuido con que esta leyenda sea engañosa ante los ojos de la veracidad biográfica y nos haga identificar bajo tres nombres: san Antonín de Apamea, san Antonín de Pamiers y san Antolín a un mismo santo mártir; siendo el primero nacido en Aribazos en la segunda Siria romana y martirizado en Apamea en el I siglo; el segundo nacido en Fredelacum (Fredelás, ciudad que devendrá Pamiers), apóstol de Rovergue (Aveyron, Francia) y martirizado en la Galia. Las reliquias de este santo se encontrarían en la Galia y muy probablemente parte de estas mismas reliquias sean las del tercero, las cuales fueron trasladadas hasta la ciudad de Palencia donde hasta el día de hoy descansan en su catedral.

El Martyrologio Romano confirma que las reliquias del mártir Atoninus de Pamia descansan en la catedral de Palencia, donde reciben una gran devoción. Este dato -como bien debe esperarse-, no puede ser considerado como absoluto ${ }^{10}$; pues, tal y como

8 "Acta translati corporis anno DCCCLXXXVII prorsus fabulosa: cultus S. Antonini in Hispania, qui verosimiliter non est inchoatus ante irruptionem Saracenorum, seculo VIII factam", ibid., p. 345.

9 Hernández Amez (2008: 367) nos aclara: “En el Martyrologium aparece en la página 376 y aquí se dice que se alude a él en un libelo de un monje apamiense, obispo de Siria (la segunda Siria romana), del año 536".

10 Pamiae in Gallia S. Antonini martyris, cujus reliquiae in ecclesia Palentia in Hispania magna veneratione asservantur. Hunc Martyrologii textum facile ab omni errore excusare possemus, etiamsi certum esset sanctum Antonimum ibidem 
ocurre en otras vidas de santos, hay una considerable cantidad de textos que buscan validar la advocación de un culto local a favor de una región por encima de las otras involucradas en la leyenda. Además, este hecho se acentúa en un grado de complejidad poco común en el caso de san Antolín, ya que desde tiempos remotos se han gastado ríos de tinta tratando de ubicar la historicidad de este personaje, situando -principalmente, y por encima de otros cuantos- $^{11}$, a dos santos protagonistas de esta discusión: un san Antonín de Siria y otro san Antonín de Pamiers, de los cuales, o bien este último no es más que una transposición tardía del primero, o bien dos personajes distintos. Incluso los mismos Bollandistas -verdaderas autoridades hagiográficas-consideran que en el caso de san Antolín hay nudos inextricables al grado que hasta el día de hoy esta cuestión sigue abierta ${ }^{12}$. Como es posible apreciar - proporcionados estos antecedentes-, nos encontramos ante un caso que ha seguido una serie de ramificaciones que se tornan complejas al momento de buscar la historicidad de este santo mártir. Complicaciones que persisten si se intenta seguir el traslado de las reliquias de san Antolín desde Galia hasta Palencia ${ }^{13}$.

Tradicionalmente se tiene asumido que el traslado de las reliquias de san Antolín fue realizado por Wamba, monarca visigo-

non esse passum, cum Apamiis in Gallia Narbonensi annuntiari potuerit ob celeberrimam venerationem, qua ibidem colitur a multis seculis. Hinc in Martyrologio Parisiensi recte memoratur his verbis: Eodem die, natalis sancti Antonini martyris, Apamiarum in Occitania patroni; cujus nomine extat ecclesia in dioecesi Parisiensi apud Castra Brigensia, Verum non aeque excusari potest annotatio Baronii, nisi revera Apamiis in Occitania passus sit Antoninus. Haec enim observat: Passus est autem non Apameae in Syria, ut multi opinati sunt; sed Pamiae apud Tolosam, ut constat ex tabulis ecclesiae Palentiae, in qua ejus dies natalis solennitem agitur, ubi sacrae corporis ejus reliquae requiescunt (Acta Sanctorum: 343 ).

11 Para una revisión de los otros santos que pudieran tener un vínculo con la leyenda de san Antolín véase Jean-Luc Boudartchouk (2002: 15-57).

12 Ibid., pp. 17-22.

13 “L'église possédait dans deux reliquaires des XIIe-XIIIe siècles une relique d'un os long du bras, ainsi qu'une omoplate", ibid., p. 33. 
do afamado por mantener en prosperidad el reino, protegiendo esmeradamente a la Iglesia cristiana. Según como se refiere en el concilio undécimo de Toledo, gran parte de su éxito se debe a que supo llevar victoriosamente las armas contra distintas rebeliones ${ }^{14}$. Una de éstas tuvo lugar en Galia, de la cual tenemos noticias en la Historia Wambae ${ }^{15}$, escrita por Julián de Toledo probablemente en los últimos años del 670 d.C., o quizá cuando se convirtió en obispo en el año 680 d.C. La Historia Wambae narra el periodo comprendido entre los años 672-673 d.C. y el texto está concebido más como obra retórica de instrucción política que como crónica detallada de lo acontecido ${ }^{16}$. No obstante, gracias a este documento de entrañable importancia para la historia visigoda, sabemos que las Galias eran consideradas como una tierra "madre de la perfidia e infiel"17, tierras que en específico se ubicaban en la Galia narbonense y de las que dicho rey monarca salió vencedor. Sin embargo, no hay una sola mención en toda la Historia en torno a las reliquias de san Antolín, ni de su traslado en el siglo VII desde Narbona hasta Palencia. Si acaso, el único pasaje de este texto en el que pudiera inferirse la apropiación de las reliquias, como parte del botín de guerra, sea en el párrafo veintiséis, aquel que refiere que tras haber detenido a Paulo -duque traidor que junto con otros rebeldes se alzaron contra Wamba-, y tras reparar la ciudad asaltada, el monarca visigodo ordena que se conserve toda la abundancia del tesoro que habían ganado no por avaricia -como era de esperarse-, sino por amor divino, es decir, para que los asuntos sagrados puedan más fácilmente separarse de Dios y restituirse a los cultos divinos, pues

14 Así lo afirma Bernardino Llorca (1964: 675).

15 Tuve la oportunidad de consultar la edición de T. Mommsen (1976: 213-244).

16 Tal y como lo explica Roger Collins (2004: 70).

17 "Huius igitur gloriosis temporis Galliarum terra, altrix perfidiae, infami denotatur elogio, quae itique inextimabili infidelitatis febre uexata genita a se infidelium depasceret membra" (Historia Wambae: 5). 
ya lo dice el sabio: "si no se trajese el botín a las sagradas iglesias, no habría de dónde hacer que floreciera su erario":

Tertio quoque die, quod fuit quarto Nonarum Septembrium, Paulu tyrannus celebri captus detentione devincitur. Sed post haec religiosi principis animus de reparatione inruptae urbis sollicitus statim murorum cava reformat, incensas portas renovat, insepultis tumultum praestat, incolis ablatam praedam restituens et exulcerata quaeque publico aerario fovens. Iubet tamen thesauri omnem quam ceperant copiam diligentiori servare custodia, non avaritiae quaestu inlectus, sed amore divino provocatus scilicet ut res sacratae. Deo facilius possent secernere et cultibus divinus restitui. Cumulauerat enim nafandissimus ipse Paulus peccato peccatum, dum tyrannidi adiungeret sacrilegium. Nam, ut quidam sapiens dicit: 'nisi sacris ecclesiis intulisset spolium, non esset, unde suum floreret aerarium ${ }^{\prime 18}$.

No sé si esta es una de las "alusiones" de las que habla Carmen García (1966: 35) cuando estudia las fuentes para el estudio del culto de los santos en época visigoda, de las cuales, dice que en el texto de Julián de Toledo hay algunas de éstas referidas a basílicas de santos ${ }^{19}$. Lo cierto es que sería contribuir con el enredo aquí planteado si quisiésemos validar la historicidad de las reliquias de este santo mártir con un pasaje tan incierto.

Nos hallamos, pues, ante una leyenda que es, por lo que toca a su relación con la Hispania visigoda, una mera invención literaria que intenta validar el traslado de las reliquias de este mártir a la Palencia medieval. Y ya que nos encontramos ante una obra de entrañable valor literario por ser una fabulación creada a partir de un somero antecedente histórico, me interesa destacar algunas otras obras medievales que dan cuenta de estas reliquias de san Antolín en España.

18 Ibid., p. 26.

19 En la Historia Wambae (p. 3), además de la mención de la iglesia pretoriense de los santos Pedro y Pablo: "In praetoriensi ecclesia, sanctorum scilicet Petri et Pauli", yo no encuentro ninguna otra alusión a basílicas de santos. 
Una de las primeras menciones la encontramos en la crónica De rebus Hispanae, escrita por el arzobispo de Toledo Rodrígo de Ximénez de Rada durante el siglo XIII, es decir, aproximadamente dos siglos después de la restauración de la diócesis de Palencia (1035 aproximadamente), en esta obra se narra, a propósito del rey Sancho, una aventura que le ocurrió: estando el rey de caza en Palencia, perseguía un jabalí que se introdujo en una cueva donde había una cripta consagrada a san Antolín. Disponiéndose el rey a matar en el lugar sagrado, Dios paraliza su brazo derecho imposibilitándole usar el venablo. Acto ocurrido, el rey echado de rodillas ruega la piedad de san Antolín, a quien consagrará una iglesia que no será otra más que la propia catedral de Palencia erigida en ese mismo lugar ${ }^{20}$.

Nuevamente la invención propia del ámbito literario es el remanente que prevalece por encima de la anécdota histórica verificable. Bien conocida es la relevancia del rey Sancho III el Mayor de Navarra para la restauración de la sede palentina bajo la tutela de Bernardo, -uno de los eclesiásticos más afines a su persona-, enviando a Roma al obispo Poncio para gestionar los oportunos permisos de la santa sede. Acto que sirvió para terminar con los conflictos entre Castilla y León durante el siglo XI por la posesión de tierras, las cuales ganaron un sentido de unidad del que había carecido hasta entonces ${ }^{21}$; pero el milagro en el acto de la

20 Hic Sancius dum quadam die se in venerationis studio recrearet aprum secutus, contigit in civitate olim nobili, tunc deserta, quae Palentia dicebatur, cryptam in forma ecclesiae invenire, \& altare in honorem sancti Antonini martyris adhuc exstans. Ad quam cum aper fugiens advenisset, \& rex vibrato venabulo feram in crypta occidere voluisset, divino percussus miraculo, quod proposuit, non potuit adimplere. Obriguit enim brachium ejus dextrum, \& sic aper illaesus evasit. Rex autem conversus ad preces, beati martyris Antonini suffragium imploravit, \& illico destitutus jussit civitatem diruptam reparari, \& super cryptam ecclesiam aedificari, \& procuravit ibidem episcopum consecrari, \& totam civitatem cum omnibus terminis \& pleno dominio episcopo \& ecclesiae donatione obtulit liberali, villas \& possessiones alias superaddens, quibus adhuc hodie gaudet ecclesia Palentina" (Acta Sanctorum: 346$)$.

21 Así lo aclara Eloy Benito Ruano (2003: 22-23). 
caza fue el motivo literario que prevaleció, pues éste mismo, con leves variantes, se repite traducido de la De rebus Hispanae en la Primera Crónica General de España que mandó componer Alfonso el Sabio y se continuaba bajo Sancho IV en 1289:

Este rey don Sancho seyendo en Castiella, corrie un día mont, et acaesçio que fallo un dia un puerco montes; et yendo empos el, metiosele en una çibdad que estava estonces yerma -et es aquella que agora dizen Palencia- et entro en una cueva que avie y fecha en guisa de eglesia, et en ella un altar fecho a onrra de Sant Antolin martir -et ell altar es aquel que oy en díaestá y aun muy onrrado et de grandes vertudes- et el rey quel quisiera matar dentro en aquel santo logar, fue ferido del Nuestro Sennor Dios por un miraglo quel contescio y: que assi como le el quisiera ferir con el veneblo, que se le torcio el braço diestro de guisa quel non pudo tanner. Et por este avenimiento finco el puerco quel non mato. Et el rey quando aquello vio, echosse luego a priezes en oración, et rogo a la piedad de Sant Antolin martir quel oviesse mercet et quel tolliesse aquel mal. Et el rey fue luego sano de su braço ${ }^{22}$.

En tiempos de Sancho IV (1284-1295) -y como dato curioso en esta pesquisa de documentos-, encontramos que, bajo la supervisión de éste mismo, la catedral de san Antolín y sus reliquias forman parte de los elementos que conforman los escritos oficiales de la época, los cuales suelen reafirmar el poder del obispo sobre la ciudad palentina, tales como una carta del 18 de marzo de 1283 titulada: Sentencia dada por el obispo de Calahorra, por mandado del infante Don Sancho, en el pleito entre el concejo de la ciudad y la Clerecía palentina. El resultado final es claramente favorable al obispo y cabildo, donde aparece el siguiente dato:

Otrosi, sennor, non catando [los del conçeio de Palencia] ondra de las santas reliquias de Sant Antolín levando las los canónigos en processión a muy gran on/ dra e a pro dela villa e a serviçio de Dios, quisieron matar los canónigos que las trayan e por fuerça dellos

22 Primera Crónica General de España (1977: 480-481). 
fizieron tornar las dichas reliquias a Santa Maria de Villa Moriel e contodo esto non los dexaron entrar enla eglesia e ovieron las a poner enlas eras de y de Villa Moriel ${ }^{23}$.

Las reliquias de san Antolín fueron testigos de la conflictividad que vivió Palencia durante el siglo XIII, tal y como puede leerse en este fragmento. $\mathrm{Y}$ entre estas disputas, nació otro texto anónimo que también refiere la anécdota que encontramos en la De rebus Hispanae, aunque esta vez relatada de una manera más sucinta, me refiero a las Mocedades de Rodrigo ${ }^{24}$ poema que sin duda alguna, por motivos eclesiásticos, intenta unir la fama de Rodrigo de Vivar con Palencia:

Bravo era el val de Palencia, ca non avía i poblado

si non do llaman Santa María el Antigua, do morava el conde lozano 105

Saliéronse a folgar desque ovieron yantado,

e passaron las aguas amos de mano a mano.

Afondose la mula, con el rey, en un soterraño;

acórrense las gentes e sacaron al rey en salvo.

Por los braços quebró la mula; non la cavalgó más omne nado.

El rey tendió los ojos e vio por el soterraño

descender una escalera de un canto labrado.

Demandó por un cavallero que dezían Bernardo.

Diz: -Entra, Bernardo, por essa escalera e cata este soterraño.-

Dixo Bernaldo: -Señor, plázeme de grado.-

Bernardo, cuando descendió, vio un pozo cavado.

E a par de aquel pozo vio estar un altar,

et de susso un escripto, et començolo de catar;

falló que sant Antolín mártir yazía en aquel logar;

et vio una piedra con letras, et començola de catar;

e vio que trezientos años avía que era somido aquel logar.

E vínose para el rey, e díxol' en poridad:

-Señor, commo me semeja, cuerpo santo yaze en este logar.-

23 Jesús Coria y Santiago Francia (2004: 58).

24 En torno a la fecha y transmisión del texto, y para evitar confusiones, se distingue entre la Gesta (fecha de redacción) y las Mocedades de Rodrigo (fecha de la copia que ha llegado hasta nuestros días), ubicando a la primera en el siglo XIII y la segunda en el XIV o primeros años del XV, véase Mocedades de Rodrigo, ed. de Juan Victorio, Espasa-Calpe, Madrid, 1982, pp. LIII-LIV. 
Cuando lo oyó el rey, al conde fue tornado,

et dixo: -Ay, conde don Pedro, datme este logar en camio e siempre vos lo gradeceré en cuanto fuere durado, et darvos he por él a Campó, fasta en la mar [.............. .Allí dixo el conde don Pedro al rey: -Plázeme de grado.Danse las verdades et otorgáronse el cambio ${ }^{25}$.

Tras este breve repaso es posible ver que una constante en la leyenda de san Antolín es la adición de motivos literarios, como el de la Primera Crónica General, donde el que caza es cazado por Dios mediante alguna manifestación milagrosa ${ }^{26}$, o la mula que se va al fondo del agua, de no ser por ella, el rey no hubiera reparado en el pozo que conducía a las reliquiás de san Antolín; motivos literarios que contribuyeron, entre otras cosas, a justificar la restauración de la diócesis palentina, poseedora, según un reconocimiento hecho durante el siglo XIX, de las reliquias arriba señaladas ${ }^{27}$.

Una vez revisados las características y el alcance literario de esta leyenda hagiográfica, estudiemos cómo la recogen los manuscritos castellanos medievales y el incunable.

\section{San Antolín en la Compilación A, la Compilación B y el Flos sanctorum con sus ethimologías}

Como viene adscribiéndose desde el clásico trabajo de Thompson y Walsh (1986-87: 17-28), la Compilación A o Gran Flos sanctorum se compone de los siguientes manuscritos: 780,

25 Mocedades de Rodrigo (2006: 7-8).

26 Tal y como ocurre en la vida de san Eustaquio y su versión caballeresca en el Cavallero Pláçidas o en el Poema de Fernán González.

27 Boudartchouk art. cit., p. 33. Hoy en día, la devoción hacia san Antolín sigue presente, pues cada 2 septiembre la catedral de Palencia acoge a cientos de palentinos que conmemoran en honor de san Antolín el día grande de las fiestas y ferias de la capital, no perdiendo la costumbre de beber agua del pozo de la cripta del templo, a la que le atribuyen, según la tradición legendaria, propiedades curativas. 
12.688, 12.689, de la Biblioteca Nacional; y h-II-18 y h-III-22, de la Biblioteca de El Escorial. Todos ellos datan del siglo XV. Por su parte, la Compilación B se compone de los siguientes manuscritos: h-I-14 y k-II-12, de la Biblioteca de El Escorial; 15.001, de la Biblioteca de Lázaro Galdiano; 8 y 9, de la Biblioteca de Menéndez Pelayo; y el m-II-6. Todos ellos también datan del siglo XV, excepto el 9 y probablemente el 8, procedentes del siglo XIV ${ }^{28}$. De entre estos manuscritos, la vida de san Antolín se encuentra registrada en ambas compilaciones, respectivamente en el ms. 12.689, de la Compilación A, y en los manuscritos k-II-12 y h-I14. Esto refleja una cierta popularidad entre los copistas de estos manuscritos, ya que, entre las adiciones que no proceden de Vorágine, sólo dos casos de santos no españoles se reservan el privilegio de aparecer tanto en una Compilación como en otra: santa Bárbara y san Antolín.

El texto que sirve de fuente para cada una de las tres versiones es, sin duda alguna, una vida de san de Antonín Fredelás-Pamiers atribuida al papa Pascal en el siglo XII. Esta vida es calificada por los Bollandistas de fabulosissima. Según estas autoridades hagiográficas, este texto es un documento poco ordinario, muy alterado por la intermediación de una copia tardía ${ }^{29}$, pues la mayoría de los nombres propios y topónimos son irreconocibles en relación con aquellos que se encuentran en otros textos más tempranos. A grandes rasgos, el contenido de esta vida es el siguiente: inicia la vida de san Antonín ubicando su nacimiento en Apamia, en Tolosa, en los tiempos de los reyes Pippinus y Theodorico. A continuación, en el segundo párrafo, se nos muestra a san Antonín en conflicto con Theodorico, partiendo a Salerna en Italia donde vive en una ermita, se convierte en diácono y hace varios milagros. En el tercer párrafo se da cuenta del milagro del

28 Véase Vanesa Hernández Amez (2007: 673-674).

29 Boudartchouk, art. cit., p. 20. 
agua $^{30}$, éste se ofrece como una adaptación amplificada de otras versiones más tempranas, verificándose así que este milagro quizá sea uno de los más remotos de los que se le atribuyen a este mártir ${ }^{31}$. Posteriormente se nos dice de san Antonín en Roma, el rey Pippinus y santo Othveo; después de una entrevista con Pippinus, Antonín, acompañado de san Othveo obispo, marcha a una ciudad llamada Brugdunensem (Frugdunensem, Frédelas), donde liberará a un poseído. Después, con san Lino obispo, parte a una región llamada Noviomensem (Mieux); y finalmente a Vallis Nobilis, donde conoce a Festus. Del párrafo quinto al octavo la acción se desarrolla en Toulouse, toda ésta aporta nuevas adiciones a la leyenda: Theodorico le propone sede Tholosensi, in episcopatu videlecet sancti Saturnini; pero él no lo acepta, prefiere permanecer como diácono. Acusado de tener una aventura con la esposa del rey, es confinado en una cárcel cuyo nombre era Spelunca Nociva. Es entonces cuando interviene un nuevo personaje que tiene por nombre Almachius, un excelente varón hijo de patricios. Almachio alivia a Antonín del peso de sus cadenas; pero siendo descubierto, es mandado ejecutar por orden de Theodorico desde los alto de un precipicio. Almachio, es ayudado por un ángel que lo toma en su caída; más tarde, Theodorico se sorprenderá por reencontrar a Almachio sano y salvo en una ciudad llamada Penthoniam (Appameam). Almachio entonces predicará al rey su fin en la guerra Magalonensem (Catalaunensem) contra el emperador Pipinum, profecía que se cumplirá. Su sucesor, un pagano llamado Galacius ${ }^{32}$, intenta convertir a san Antonín-siempre encarcelado-al culto de los ídolos. Antonín lo

30 A grandes rasgos el milagro se resume de la siguiente manera: caminando san Antonín con sus seguidores -con gran sed y sin poblado próximo-, hizo su oración a Dios. Acabada ésta, golpea la piedra con su bordón, de la cual brota una fuente que, con el tiempo, se sabrá que cuantos beban de ella sanarán de cualquier mal.

31 Y el que a la fecha pervive en la devoción de la comunidad palentina hacia este santo, tal y como indicábamos arriba.

32 Sobre la relevancia de este personaje, véase Ibid., p. 21. 
rechaza, bautiza y convierte a paganos in nomine sanctae et individuae Trinitatis. Antonín es entonces puesto en una olla repleta de azufre y de plomo, dentro de ella se cumplen más bautismos y milagros, saliendo ileso. Galacius llama entonces a los sabios y a los pontífices del templo a fin de convertirlo al culto de los ídolos. No obstante, basta con que el primero y el mejor de estos pontífices de los ídolos fracase en el intento para que el resto ni siquiera se atreva a ello; entonces el rey decide arrojarlo en el río Garonne con una pesada muela de piedra alrededor del cuello, sale ileso de esta condena bautizando a los que le arrojaron al río. Por cansancio, Galacius lo hace liberar. Antonín regresa a Fredelas-Pamiers: reversus est Appamiam, donde se reencuentra con Almachio; se convierten entonces en ermitaños en un lugar donde era una fuente que llamaban Orientalis, donde se les une un cierto preste Juan. Un rey que decían Methopius está sobre sus huellas y sus hombres encuentran a estos tres. Delante del rey rechazan el culto de los ídolos y son llevados al río Arregiae, cuyas aguas corren cerca de Appamiam. Antonín es el primero en ser decapitado junto al río Arregiae, la espada cortó a la vez la cabeza, omóplato y el brazo derecho. Inmediatamente después Almachio y Juan son decapitados. Methopius y Effrasia intentan en vano hacer desaparecer las reliquias arrojándolas al río. La vita termina con la veneración de los cuerpos que existe en los tiempos de la redacción de este documento:

Beati martirys venerant, corpus ejus cum magna devotione quaesierunt sed sine capite repertum digna veneratione susceperunt et cum corporibus martyrum Johannis presbyteri et Almachi pueri, qui cum ipsu passi sunt, sepulturae tradiderunt ${ }^{33}$.

Los manuscritos k-II-12 y h-I-14 siguen, con sus respectivas variantes, el texto del papa Pascal, salvo una importante adición que no registra esta última versión del siglo XII: las dos versiones 
de la Compilación B añaden una larga parte final que va unida al intento de Effrasia de hacer desaparecer las reliquias. Esta parte final cuenta que una vez arrojadas las reliquias al río - por intervención de Dios-, dejó de correr el agua para que los cristianos las hallasen; posteriormente se refiere que la cabeza y el brazo de san Antolín, que fueron echados en aquel río, fueron rescatados y guiados por ángeles en una nave hasta que retornaron a Val Noble, donde Festo tiene oportunidad de testificar este milagro y darles sepultura. A continuación se dice que, después de gran tiempo, nadie recordaba dónde yacían éstas, ocurriendo el milagro del redescubrimiento de las reliquias debido a un toro que lamía la piedra donde yacía enterrado san Antolín; desenterrados los cuerpos, son trasladados a la iglesia de "sant Martín" en la ribera del río Arregia. Terminan ambas versiones indicando las respectivas fechas para la celebración de este santo mártir, al que le corresponden dos, una cuando muere y otra cuando fue trasladado a esta última iglesia.

Esta parte final tiene por fuente dos documentos, en primer lugar un texto titulado De mirabili capitis Anthonini inventione y el De extollenda corporis beati Anthonini inventione; ambos textos se encuentran en el De mirabilibus ejusdem [Sanctus Antonini martyris] que contiene el gran legendario de la abadía de Moissac ${ }^{34}$. Esto nos lleva a suponer que quizá la copia hoy perdida que sirvió de fuente para las versiones de la Compilación $\mathrm{B}$ reunía tanto la vita del papa Pascal como los dos textos arriba referidos; o que los copitas del k-II-12 y h-I-14 tenían frente así varios de estos textos no presentados en una sola fuente y sobre los cuales fue conformada la vida de san Antonín en castellano.

Por su parte, la versión de la Compilación A presenta el inconveniente de que hay algunos folios que son, prácticamente, ilegibles; además -a expensas de una futura revisión exhaustiva

34 Ibid., pp. 47-49. Además, Nicolas Bertrand, en su Tholosanorum gesta (1515), ofrece un dossier hagiográfico sobre Antonín de Pamiers, donde aparece tanto la vita de papa Pascal como estos dos últimos documentos, cf., ibid., p. 44. 
de este santoral-, la vida de san Antolín permanece incompleta: ésta inicia en el folio LXVc, pero al llegar al folio LXVIIa hay una transposición con la parte final de vida san Lupe, por este motivo no podemos saber si la versión del ms. 12.689 también presentaría la adición de los dos mencionados textos latinos en su parte final, pues nos facilitaría el trabajo de saber si este santoral también toma por fuente aquella sobre la que se basa la Compilación B o si solamente toma por fuente la vita del papa Pascal. No obstante, y pese a estas deficiencias, aun así es posible destacar que, como se ha venido estudiando en los últimos años, la versión de la Compilación A difiere de las de B., pues, por ejemplo, entre varias caracerísticas distintivas destaca que en la primera se refiere un número más reducido de vidas de santos, pero de mayor extensión; y, en la última, se presenta un mayor número de vidas de santos pero más concisas; además, en la Compilación A se recogen más vidas que no proceden de Vorágine.

En el caso de la vida de san Antolín, la distinción entre una y otra Compilación no es tan radical ${ }^{35}$. De manera patente aquí se marca el hecho que la versión del k-II-12 y h-I-14 poseen pocas variantes entre sí, al grado que puede realizarse una lectura simultánea sin que al hacerlo se pierda la línea argumental que se va presentando. Esto no ocurre con la versión del 12.689, la cual, dejando de lado las deficiencias que arriba hemos indicado, parece ser que no se corresponde con lo que se presenta en la Compilación B. Por estas circunstancias, el manuscrito de la Compilación A queda descartado como una de las versiones que sirviera de fuente para la presente en el Flos sanctorum con sus ethimologías.

Por su parte la vida de san Antolín en el incunable de Washington es una versión con algunas adiciones considerables en

35 Como la que se presenta en la vida de santo Toribio, donde es substancial la diferencia de la versión presente en el ms. k-II-12 (mucho más sucinta) y la del ms. 780 (de mayor extensión), pues éste último aporta elementos legendarios sin precedente alguno en otra versión manuscrita castellana. Para más detalles véase Cortés Guadarrama (2010: 431-448). 
relación con los textos manuscritos de B, de ahí su mayor extensión; ya que mientras que el ms. k-II-12 comprende del folio 184a al 187c; y el del ms. h-I-14, del CCXLId al CCXLVb, el texto del incunable comprende del folio 195b hasta el 199d. Desde su redescubrimeinto, viene adscribiéndose que gran parte del contenido que ofrece este incunable se encuentra relacionado con los manuscritos de la Compilación $\mathrm{B}$, y que su relación con éstos yace en una de dos ramificaciones ubicadas dentro de esta familia, llamadas B1 y B2. La primera está integrado por los manuscritos k-II-12, h-I-14, m-II-6 y la sección final de 15.001; la segunda (B2), que nace de una lectura y adaptación de los contenidos de la primera (B1), está compuesta por la sección inicial del 15001 y los mss. 8 y $9^{36}$. El incunable de Washington se encuentra más allegado al contenido de B1 ${ }^{37}$. Tomando como punto de análisis la vida de san Antolín, esta teoría se confirma, pues el incunable parece seguir la línea argumental de las versiones manuscritas k-II-12 y h-I-14. No obstante, la versión impresa posee algunos elementos que, o bien permiten especular sobre otra fuente hoy perdida, cercana al ms. h-I-14, que posee mayor afinidad con el Flos sanctorum con sus ethimologías ${ }^{38}$ o bien sólo se deben a la propia creatividad del compilador; creatividad que pondera los detalles narrativos, principalmente aquéllos que integran las manifestaciones milagrosas A continuación un breve cuadro con un segmento milagroso que ilustra los rasgos distintivos de cada testimonio:

36 Aragüés Aldaz, art. cit., pp. 197-215.

37 Tuve oportunidad de corroborar, ampliar y rectificar las pioneras obsevaciones Aragües Aldaz, véase Cortés Guadarrama (2011: 31-53).

38 La fiesta de la Natividad del Señor, presente en la Legenda aurea, yace conservada -y quizá fue difundida- sólo en uno de los manuscritos de B, el h-I-14. Los otros que registran esta fiesta, es decir, los mss. k-II-12, 15001 y 9, presentan otra versión ajena a Vorágine, la cual refiere por fuente a los evangelios "Pastores loquebantur" y el de san Mateo. Cierto es que una filiación no puede construirse sobre lecturas comunes; pero los errores en lecturas coincidentes como ésta estrechan la relación entre el ms. h-I-14 y el incunable de Washington. 


\begin{tabular}{|c|c|c|c|c|}
\hline Compilación & \multicolumn{2}{|c|}{ Compilación B (B1) } & \multicolumn{2}{|c|}{ Familia impresa de B } \\
\hline ms. 12.689 & ms. h-I-14 & ms. k-II-12 & $\begin{array}{c}\text { Flos sanctorum } \\
\text { con sus } \\
\text { ethimologías }\end{array}$ & $\begin{array}{c}\text { La leyenda de } \\
\text { los santos } \\
(1499)\end{array}$ \\
\hline $\begin{array}{l}\text { E veyendo } \\
\text { muchos de } \\
\text { los gentiles } \\
\text { que sant } \\
\text { Antolín } \\
\text { estava en la } \\
\text { olla del } \\
\text { plomo riendo } \\
\text { e de la piedra } \\
\text { sufre sano e } \\
\text { sin algunt } \\
\text { themor, } \\
\text { creyeron en el } \\
\text { Salvador e } \\
\text { derribáronse } \\
\text { a los pies del } \\
\text { santo varón, } \\
\text { rogándole } \\
\text { con lágrimas } \\
\text { que le } \\
\text { pluguiese de } \\
\text { los baptiçar. E } \\
\text { el cavalero } \\
\text { fuerte de } \\
\text { Jhesu Christo } \\
\text { començolos a } \\
\text { enseñar } \\
\text { desde la olla e } \\
\text { baptiçolos en } \\
\text { el nonbre del } \\
\text { Señor }\end{array}$ & $\begin{array}{l}\text { E los que } \\
\text { metían la leña } \\
\text { deyuso de la } \\
\text { olla, quando } \\
\text { vieron a tal } \\
\text { miraglo, luego } \\
\text { se tornaron } \\
\text { christianos. E } \\
\text { sant Antolín } \\
\text { bendixo aquel } \\
\text { plomo e } \\
\text { aquella piedra } \\
\text { sufre e ello } \\
\text { tornose } \\
\text { semejança de } \\
\text { agua. E él } \\
\text { yaçiendo en la } \\
\text { olla, tomávalo } \\
\text { con la mano e } \\
\text { echávalo sobre } \\
\text { todos e } \\
\text { dávales } \\
\text { bautismo [fol. } \\
\text { CCXLIIId] e } \\
\text { todos } \\
\text { creyeron } \\
\text { firmemente en } \\
\text { Jhesu Christo }\end{array}$ & $\begin{array}{l}\text { E los que } \\
\text { metían la leña } \\
\text { deyuso, } \\
\text { quando vieron } \\
\text { tan grant } \\
\text { miraglo, luego } \\
\text { se tornaron } \\
\text { christianos. E } \\
\text { sant Antolín } \\
\text { bendiçiendo } \\
\text { aquel plomo e } \\
\text { tornándose en } \\
\text { semejança de } \\
\text { agua, e } \\
\text { tomávalo con } \\
\text { la mano e } \\
\text { echávalo sobre } \\
\text { los otros e } \\
\text { dávales el } \\
\text { baptismo, e } \\
\text { todos } \\
\text { firmemente } \\
\text { creyeron en } \\
\text { Dios. }\end{array}$ & $\begin{array}{l}\text { E quando } \\
\text { vieron } \\
\text { aquellos todos } \\
\text { que aí estavan } \\
\text { faziendo esto, } \\
\text { que Dios } \\
\text { mostrava } \\
\text { vesiblemente } \\
\text { tamaño } \\
\text { miraglo, e ellos } \\
\text { se quemavan } \\
\text { alderredor de } \\
\text { la lunbre do } \\
\text { estavan, que } \\
\text { ardía tanto so } \\
\text { la tina de la } \\
\text { lunbre, e que } \\
\text { sant Antolín } \\
\text { non lo sentía, } \\
\text { convertiéronse } \\
\text { todos a la } \\
\text { creencia de } \\
\text { Dios. }\end{array}$ & $\begin{array}{l}\text { E quando } \\
\text { vieron los que } \\
\text { ay estavan esto } \\
\text { que Dios } \\
\text { mostrava } \\
\text { visiblemente } \\
\text { tan grand } \\
\text { milagro, e ellos } \\
\text { se quemavan } \\
\text { alderredor de } \\
\text { la lunbre e que } \\
\text { tanto ardía } \\
\text { debaxo de la } \\
\text { tina, e sant } \\
\text { Antolín no lo } \\
\text { sentía } \\
\text { convertiéronse } \\
\text { todos a la fee } \\
\text { de Jhesu } \\
\text { Christo. }\end{array}$ \\
\hline
\end{tabular}

Las aportaciones del Flos sanctorum con sus ethimologías, ausentes en las versiones manuscritas de la Compilación B, se trasmitirán en el pariente impreso más logrado e ilustrado de esta familia: La leyenda de los santos (c. 1499), resguardado en la British Library (IB 53312). Ese bello ejemplar que evitó muchos de los fa- 
$1 \operatorname{los}^{39}$ de su pariente, y del que repitió alguno de sus logros, como el de incluir entre sus páginas -pero ya en una sección especial dedicado a los santos "Extravagantes"- a un santo de vida fabulosísima excluido por Vorágine en su Legenda aurea.

Regresando al incunable de Washington, podríamos especular que la inclusión de la vida de san Antolín quizá se debió a los intereses de un compilador preocupado en destacar la relación de este santo y la diócesis palentina. A este respecto, resulta curioso destacar que otra de las adiciones del incunable no procedentes de Vorágine, la vida de santo Toribio, también se encuentra relacionado con tierras palentinas ${ }^{40}$. Por supuesto, esto no determina la procedencia del compilador. En lo que tal vez contribuya es a destacar la relevancia de esta región dentro del territorio español para conformar cultos con una devoción local, logrando establecer lazos de unidad cristiana aún cuando se echara mano a unas vidas de santos extremadamente fabulosas y descartadas por otros compiladores, como Vorágine.

\section{Los milagros de san Antolín}

Los estudiosos de la literatura hagiográfica medieval interesados en destacar la aportación de esta clase de textos para el lector de a pie ${ }^{41}$, pueden encontrar un singular ejemplo en el caso

39 Tales como abundantes inconsistencias al ofrecer las festividades de Cristo y una enorme carga de textos doctrinales tomados directamente de la Legenda aurea, sin precedente en las versiones manuscritas de la Compilación B. Dichos textos son los siguientes: Natividad del Señor, Circuncisión del Señor, Epifanía del Señor, la Septuagésima, la Sexagésima, la Quincuagésima, la Cuaresma, el Ayuno de las cuatro Témporas, Pasión del Señor, Resurrección del Señor, Ascensión del Señor, Espíritu santo (Pentecostés), Asunción de la Virgen María, Natividad de la Virgen María, Todos los santos, Conmemoración de las almas, la Dedicación de la Iglesia y el Adviento del Señor.

40 Entre otras cosas, santo Toribio combatió la herejía priscilianista y fundó el monasterio de Liébana, véase Cortés Guadarrama (2010: 432-437).

41 Baños Vallejo (2009: 261-272). 
que hoy nos ocupa. En efecto, por numerar sólo los milagros más sobresalientes, cómo ignorar que san Antolín fue puesto en una olla repleta de azufre y de plomo, que dentro de ella se cumplieron más bautismos y milagros, y que salió ileso de ahí pues: "ante dizía que estava en muy dulces vaños e en grant folgura (f. 197c)", ${ }^{42}$ cómo olvidar que fue arrojado a un río con una pesada muela de piedra alrededor del cuello, que salió ileso de esta condena: "la muela andando sobre el agua quatro días e sant Antolín andava sobre la muela (f. 198a)" y que bautizó a los que le arrojaron al río; cómo pasar por alto que fue decapitado, y que en este acto, la espada cortó a la vez la cabeza, omóplato y el brazo derecho; que una vez arrojadas sus carnes al río: "el río non corrió por aquel lugar (f. 198d)" para que los cristianos las hallasen; después, se nos dice que su cabeza, su omóplato y su brazo fueron tomados por ángeles y echados en una barca que entró en varios ríos, y que los ángeles: “en semejança de dos águilas blancas, que guiávan la cabeça con el costado por aquellos ríos (f. 199a)". ¡Y todo esto para cumplir la promesa de visitar a un antiguo amigo!: "E quando el rey Festo lo vio venir por el río, maravillose mucho qué podría ser, e estubo orilla del río, esperándole. E después [...] entendió que en aquella varqueta podría venir el mártir, su amigo (f. 199a)". Tras este viaje, el rey amigo finalmente le construirá una iglesia donde guardará sus restos. Pero ahí no termina la historia. Gran tiempo después nadie recordaba dónde yacían estas reliquias. Y es gracias a un toro, bravo y grande que: "lamía en el luzillo del mártir sant Antolín (f. 199b)", cuando ocurre el milagro del redescubrimiento; desenterrado los restos, son trasladados a otra iglesia para por fin terminar con la narración de este santo.

Cada uno de estos milagros forma parte de una realidad que se rige por sus propias leyes, y a este hecho se adscribe la lla-

42 Los números de folios los tomo de mi citada edición del Flos sanctorum con sus ethimologías. 
mada categoría textual de lo maravilloso ${ }^{43}$, que en el contexto religioso en el que se desarrolla nuestra texto se corresponde con lo milagroso. El salto de esta última categoría a la de lo fabuloso se da por el cúmulo de realidades milagrosas que entrelazan un ir y venir constante entre lo geográfico y lo simbólico, entre lo imaginario y lo verídico, entre lo social y lo ideológico, tal y como ocurre en la literatura folklórica. En efecto, san Antolín es un caso más próximo a la cultura popular del folklore, pues debemos recordar que es un solitario errante que busca alejarse de cultura erudita de la ciudad. Un santo que en compañía de sus seguidores se aleja a los bosques: "E después, estando allí un rey, que dizían Metorio, enbió sus omnes a caçar. E acaecieron por aquel lugar, e fallaron allí a sant Antolín e a Almachio, que estavan en oración contra nuestro Señor (fol. 198b)". Este es un santo que, dentro del sistema de valores de los hombres del Occidente medieval, como señala Le Goff (2008: 49), se opone al mundo, o sea, a la sociedad organizada, a la corte. Con san Antolín, lo simbólico de su leyenda representa un dualismo que se opone a lo construido, cultivado y habitado, su mundo yace en lo salvaje, en el bosque y en el río. Estos dos últimos espacios geográficos, nos recuerda Le Goff, que son "los equivalentes occidentales del desierto oriental" que inspiró las mejores historias de eremitas errantes de los primeros tiempos del cristianismo. Estos elementos simbólicos de su leyenda, propios de un "rebelde" que se sale de las reglas establecidas del mundo medieval, quizá fueron los mismos que hicieron que Vorágine descartara esta narración de su Legenda aurea. Evidentemente, existen vidas de santos más fabulosas que ésta, baste recordar el caso de san Brandán, ${ }^{44}$ (santo

43 Así lo dice Bottón Burlá (1994: 15): “Cuando el hecho extraño no se puede explicar segú las leyes del mundo conocido por nosotros, del mundo real, sino que obedece a otras leyes, a reglas que son las de otro sistema diferente del nuestro, nos encontramos dentro del mundo de lo maravilloso".

44 Una primera versión en castellano de esta leyenda corrió a cargo de la traducción de Marie José Lemarchand, en Selección de lecturas medievales, 3, Ediciones Siruela, 1983. 
que tampoco fue compilado por Vorágine); pero, en el caso de san Antolín, el cúmulo de los milagros aquí descritos y la imposible amalgama de por lo menos dos personajes históricos en un sólo héroe transmisor de la palabra de Dios no cristalizó en el criterio selectivo de una obra compilatoria como la Legenda aurea, donde predomina un eje de leyendas bien definido por Arnold van Gennep (1982: 119-120):

Las leyendas hagiográficas se proponen la justificación de los cultos locales de que los santos son objetos [...] esta categoría de leyendas es utilitaria. No por gusto se enumeran los sufrimientos, las aventuras, el heroísmo de los santos, sino por un fin de edificación. A este amplio fin se añade el fin preciso y local: convencer al auditorio del poder del santo y asegurar así a su culto fieles y recursos. Este doble fin, general y especial, explica las grandes tendencias de la formación de las leyendas hagiográficas.

Apegados a esta definición de justificar cultos locales, no es curioso que las características de esta leyenda, y el cúmulo de los milagros que registra, contados bajo una impronta más cercana a la fabulación folklórica que a un fin de edificación, no fueron un impedimiento para la buena acogida que tuvo en los santorales manuscritos castellanos. El carácter fabuloso de este texto pasó a un segundo plano en virtud de una fuerte advocación local en Palencia. De ahí que uno de los primeros incunables del género, como el Flos sanctorum con sus ethimologías, no sólo se apega a la cualidad "científica" de su fuente principal al ofrecernos, entre otras cosas, las etimologías de los nombres de los santos ${ }^{45}$, sino que también recoge una tradición que aseguró fieles y recursos para un santo como san Antolín, cuya vida es de lo más singular

45 Este hecho quizá se deba a las oportunidades que ofrecía la imprenta: sólo un libro estaba en condiciones de duplicar el potencial y la eficacia del manuscrito. Por fin el nuevo invento cumpliría con las expectativas de un compilador deseoso de ofrecer un completísimo santoral castellano basado en la Legenda aurea; uno que, además, por fin incluiría vidas de ciertos santos muy venerados en lo que hoy corresponde al territorio español, véase Cortés Guadarrama, (2011: 78-82). 
en el panorama textual de la literatura hagiográfica castellano medieval.

\section{Bibliografía}

AragüÉs Aldaz, José (2007): “El Flos sanctorum con sus ethimologías. El incunable, la Compilación B y la Leyenda de los santos: deudas, herencias y filiaciones", Actas del XI Congreso Internacional de la Asociación Hispánica de Literatura Medieval, I, ed. de A. López Castro y Maㅡ. Cuesta Torre, León, Universidad de León, págs. 197-215.

Baños Vallejo, Fernando (2007): “El Flos sanctorum con sus ethimologías. Primer incunable del género", Actas del XI Congreso Internacional de la Asociación Hispánica de Literatura Medieval, I, ed. de A. López Castro y Mํㅡㄴ L. Cuesta Torre, León, Universidad de León, págs. 287-297.

Baños Vallejo, Fernando (2009): “El Flos sanctorum medieval para lectores de hoy", Medievalismo en Extremadura. Estudios sobre literatura y cultura hispánicas de la Edad Media, ed. de Jesús Cañas Murillo, Francisco Javier Grande Quejigo y José Roso Díaz, Cáceres, Universidad de Extremadura, págs. 261-272.

Botton Burlá, Flora (1994): Los juegos fantásticos. México, Universidad Nacional Autónoma de México, $2^{\underline{a}}$ ed.

Boudartchouk, Jean-Luc (2002): “L'invention de saint Antonin de Frédelas-Pamiers", Mémoires de la Société Archéologique du Midi de la France, comunicación presentada el 26 de febrero, págs. 15-57.

Collins, Roger (2004): Visigothic Spain (409-711), Oxford, Blackwell Publishing.

Coria, Jesús y Santiago Francia (2004): Reinado de Sancho IV (1284-1295), Palencia, Aretusa Ediciones.

Cortés Guadarrama, Marcos (2011): El flos sanctorum con sus etimologías. Edición y estudio, Oviedo, Universidad de Oviedo. 
[Tesis doctoral publicada en CD y en línea: http://www.cervantesvirtual.com/obra/el-flos-sanctorum-con-sus-ethimologiasedicion-y-estudio/].

Cortés Guadarrama, Marcos (2010): “Santo Toribio: una variante primitiva de la leyenda en el Flos sanctorum con sus ethimologías", Expresiones de la cultura y el pensamiento medievales, ed. de Lillian von der Walde Moheno, Concepción Company y Aurelio González, El Colegio de México, Universidad Nacional Autónoma de México, Universidad Autónoma Metropolitana, Publicaciones de Medievalia 37, págs. 431-448.

Cortés Guadarrama, Marcos (2010): “De la Transfiguración de nuestro Señor en el Flos sanctorum con sus ethimologías", Estudios sobre la Edad Media, el Renacimiento y la Temprana Modernidad, ed. de Francisco Bautista y Jimena Gamba, San Millán de la Cogolla, SEMYR-Cilengua, págs. 117-128.

Cortés Guadarrama, Marcos (2011): “Para saber del antichristo e de otras cosas': sobre un índice comentado en el Flos sanctorum con sus ethimologías", Actas del XIII Congreso Internacional de la Asociación Hispánica de Literatura Medieval, (In memoriam Alan Deyermond), ed. de José Manuel Fradejas, Déborah Dietrick, Demetrio Martín y Mํㅡ Jesús Díez, Ayuntamiento de Valladolid y Universidad de Valladolid, págs. 583-598.

Fernández Rodríguez, Natalia (2007): “El Flos sanctorum con sus ethimologías. Más allá de la Legenda aurea: san Julián y santa Basilisa", Actas del XI Congreso Internacional de la Asociación Hispánica de Literatura Medieval, I, ed. de A. López Castro y Mª L. Cuesta Torre, León, Universidad de León, págs. 543-550.

García Rodríguez, Carmen (1966): El culto de los santos en la España romana y visigoda, Madrid, CSIC.

Gennep, Arnold van (1982): La formación de las leyendas, Barcelona, Alta Fulla. [1 ${ }^{\underline{a}}$ ed. en 1914] 
Hernández Amez, Vanesa (2008): Descripción y filiación de los Flores sanctorum medievales castellanos, tesis doctoral publicada en $\mathrm{CD}$, Oviedo, Universidad de Oviedo.

Hernández Amez, Vanesa (2007): “El Flos sanctorum, con sus ethimologías. Relaciones con la tradición manuscrita medieval", Actas del XI Congreso Internacional de la Asociación Hispánica de Literatura Medieval, II, ed. de A. López Castro y Mํㅡ. L. Cuesta Torre, León, Universidad de León, págs. 673-684.

Le Goff, JAcQues (2008): Lo maravilloso y lo cotidiano en el Occidente medieval. Barcelona, Gedisa. [3를 ed.]

Llorca, Bernardino (1964): “La Iglesia visigótica en su mayor apogeo", Historia de la Iglesia católica, Madrid, B.A.C., vol. I.

Menéndez Pidal, Ramón (Ed.). (1977): Primera Crónica General de España, Madrid, Editorial Gredos, t. II, cap. 799, págs. 480-481.

Mommsen, T. (Ed.). (1976): "Historia Wambae Regis", Corpus Christianorum Series Latina, vol. CXV, págs. 213-244.

Ruano, Eloy Benito (2003): “Sancho III el Mayor de Navarra. Panorámica de un reinado", Sancho III el Mayor de Navarra, Madrid, R. A. H.

Thompson, Billy B. y John K. Walsh (1986-87): “Old Spanish Manuscripts of Prose Lives of Saints and their Affiliations. I: Compilation A (The Gran flos sanctorum)", La Corónica, 15:1, págs. 17-28.

Todorov, Tzvetan (2006): Introducción a la literatura fantástica, Buenos Aires, Paidós.

Varazze, Iacopo da (1998.): Legenda aurea, ed. de Giovanni Paolo Maggioni, Firenze, Edizioni del Galuzzo.

Viña Liste, José María (Ed.). (2006): Mocedades de Rodrigo, Madrid, Biblioteca Castro, [Versión en línea en: http://www.biblioteca.org.ar/libros/150488.pdf]. 


\section{Apéndice I: Criterios de edición}

De entre los testimonios analizados en este estudio, a continuación edito la vida de san Antolín presente en el manuscrito h-I-14 de la Biblioteca del Escorial. Las razones de esta selección se fundamentan en que este es el testimonio más próximo al Flos sanctorum con sus ethimologías, santoral ya editado y estudiado que puede consultarse en http://www.cervantesvirtual.com. Existen bastantes diferencias entre una y otra versión, el lector tendrá oportunidad de comparar la que aquí se edita con la compilada en el primer incunable del género, misma que se encuentra entre las páginas 566 y 574 de mi edición.

La presente edición no pretende ofrecer una transcripción paleográfica, sino una referencia de lectura con rigor filológico que permita a los interesados una base para todo estudio consagrado a las ciencias humanas, no sólo la filología, sino la antropología, la historia, la filosofía, etc. El criterio es que todo especialista cuyo propósito de análisis sean los distintos niveles de detalles que posee un manuscrito medieval, acudirá precisamente a la fuente original, es decir, el manuscrito mismo, y no a una transcripción. Considero que en la edición de fuentes textuales con siglos de antigüedad se debe procurar ofrecer una clara y moderna transcripción, cuyo resultado sea un producto accesible destinado a expertos en el tema, pero también dirigido a profesores universitarios interesados en difundir estos textos entre sus estudiantes.

Los criterios de edición continúan en la misma línea con la que años atrás trabajé el santoral castellano más completo que hasta ahora se haya editado. Por lo tanto, normalizo las grafías que carezcan de valor fonológico y conservo las que sí pudieran tenerlo en el castellano medieval. Sin embargo, conservo algunos rasgos que no causan confusión y, en cambio, muestran sabrosos arcaísmos ortográficos, como qua-: quando, qualquier, qual; la $h$ en casos como: Jhesu Christo; la th en voces como: Theodorico; también la $n$ ante $b$ o $p$ cuando así aparezca: fanbre; y $f$ inicial 
en lugar de $h$ : fermoso, facía. Simplifico las consonantes dobles que carecen de valor fonológico, así como $r r$ en posición inicial: rreyes. En posición intervocálica, transcribo $r r$ o $r$ según corresponda a cada uno de los fonemas. Aunque son contados los casos, mantengo ss por su pertinencia en posición intervocálica: Passión, essa.

Acentúo, puntúo y separo las palabras con arreglo a las normas actuales. Sin embargo, en lo concerniente a la acentuación, distingo con acento diacrítico algunos monosílabos propios de aquella época: ý adverbio y las formas tónicas nós, vós. No señalo con apóstrofo la elisión de una vocal por fonética sintáctica, de modo que edito della, dél, dellos, y no d'ella, etc.

La consonante $c$ se conserva ante $a, o$ y $u$, en otros casos transcribo $c$. Se regulariza el uso de $i$ y $j$, según normas para vocales y consonantes y lo mismo ocurre en el caso de $u$ y $v$. No marco mediante cursiva la resolución de abreviaturas, como sí lo hice en la transcripción del Flos sanctorum con sus ethimologías. Hoy por hoy considero que esta marca en la transcripción estorba a la práctica de una lectura moderna. Finalmente, en nota al pie de página consigno el uso de algunos nombres propios y palabras peculiares cuyo uso considero merece ser rastreado en distintos textos castellanos del siglo $\mathrm{XV}$, éstos fueron tomados de la siguiente dirección en línea: http://www.rae.es, Real Acadamia Española: Banco de datos (CORDE), Corpus diacrónico del español. 


\section{Apéndice II: Ms. h-I-14. De la vida de san Antolín}

[Fol.CCXLId] Capítulo ciento e nueve, de la vida de sant Antolín.

San Antolín fue de linage de reyes e fue natural de Pamia, un castillo que es dicho de Tolosa, e fue noble de linage e muy más de santidat. E así como el lilio es muy más fermoso que las otras [e]spinas, así sant Antolín salió muy más fermoso e muy más siervo de Dios que su padre nin su madre que eran en el tienpo del enperador Pepino ${ }^{46} \mathrm{e}$ del rey Theodorico ${ }^{47}$, su tío.

E la fama deste sant Antolín sonó por todas las tierras. E así él andando en servicio de Dios, sonaron los miraglos que el Nuestro Señor Dios facía por él, ca sant Antolín era profundado en las escripturas e todo aquello que leía guardávalo muy bien en el su coraçón. E nunca se partía del servicio de Dios ca era afortalado ${ }^{48}$ en las faenas

46 “E en comjenço de su Reynado menbrandose commo su padre muchas vezes fuera vençido de Pepino Rey de los françeses por que algunas vezes avia tomado E ocupado los derechos del santo pastor de la ley xpistiana por ende por que se no leuantase alguna cosa para trabajar su folgança non solamente otorgo al papa lo que su padre avia dexado mas avn con Real largueza le dio la noble çibdat de fanençia $\mathrm{E}$ la villa de tiberiane". Pero López de Ayala, Caída de príncipes, 1402.

47 "En el tiempo del rrey Theodorico, teniendo consigo un diachono fiel cristiano, este rrey amavalo mucho haunque el non hera catholico, ca tenia la seta de los arrianos que heran erejes. E este diachono por fazer plazer al rrey, dexo la fe verdadera e tornosse arriano. E el rrey, quando lo sopo, mandolo matar deziendo: -Si tu non guardaste la fee a tu dios, bien pienso que tanpoco la guardaras a mi". Clemente Sánchez de Vercial, Libro de los exemplos por A. B. C., ca. 1400-1421.

48 “Despues desto siguese \& gomjtar lo ha el Rey çierto es que el que es afortalado en la costunbre de la cobdiçia con escaseza sobejana que es su hermana alcançale lo que acaesçe al dragon que pone en su vjentre mucha vjanda sobre lo que su natura sufre por aquella demasya que non ha en el vjrtud para lo sofryr gomjta lo pertenesçiente \& lo non pertenesçiente estonçe acaesçele por esto flaqueza \& conturbaçion en todos los mjenbros \& por tu ser con aquesta cobdiçia afortalada thesorar thesoros por esta vja alcançar te ha". Varios autores, Cancionero castellano de París, ca. $1450-1500$. 
de Dios e era lleno del Spíritu Sancto. E así [fol. CCXLIIa] como muy fuerte cavallero, començó cómo en serviçio de Dios vençiese al martirio.

E su tío Theodorico que era rey por consejo del diablo, començóle muy fuertemente a guerrear. E salío sant Antolín de Pamia e fuese para Roma, e de Roma fuese a una 20 tierra que decían Salamantica. E falló ý omnes de religión, avían todas las cosas terrenales desanparadas por el amor de Dios e bivían allí en muy grant pobredat. E con éstos vivió sant Antolín en aquel logar fasta dies ${ }^{\text {sic }}$ e ocho años, e ordenáronle de evangelio e diéronle oficio que predicase.

E començó a ser muy noble doctor e començó a predicar contra los ídolos, e predicava a los que creían en ellos e otrosí predicava contra los gentiles. E por la su santidat dél, el Nuestro Señor Jhesu Christo sanó muchos ciegos e alumbrolos, e a muchos demoniados sanava e a otros de otras muchas enfermedades.

E sant Antolín predicando la palabra de Dios muy afincadamente, e él estando una vegada ante los gentiles, e bien como el rayo del sol luce entre las nubes, así estava sant An[fol. CCXLIIb]tolín, luciente entrellos e predicávales. E después que les ovo ý predicado, saliose entrellos e fuese para otra cibdat que era poblada de christianos. E duró con ellos grant tienpo e todavía deseava rescibir corona de martirio por amor de Jhesu Christo, e nunca cansava predicando de la Passión de Jhesu Christo e duró ý un grant tienpo con ellos. E él todavía esforçávase para predicar el servicio de Dios e rogava a Dios que el su trabajo non saliese en vano.

E después començó de ir para otro logar, e él yendo por su camino ovo muy grant sed e non avía aý agua que bever yendo por un yermo. E esa ora rogó al Nuestro Señor que le acorriese como Él toviese por bien, e fiço su oraçión 
e la oraçión acabada dio él su blago ${ }^{49}$ en una piedra e luego por la voluntad de Dios abriose una fuente e bevió él e los que ivan con él. E esta fuente es de grant vertud, ca dicen 50 que quantos della beven que son enfermos de qualquier enfermedat que ayan luego son todos sanos.

E en aquel tienpo el rey Pepino entró en Roma para ser enperador, e entró con él un sancto omne que decían Atueno, e era obispo. E[1] [fol. CCXLIIc] obispo oyó la fama de sant Antolín e enbió por él. E sant Antolín vínose para él e paresció ante el rey, e otrosí el rey como oyó decir de la su santidat quíxole consigo. E fuéronse para una cibdat que avía nonbre Brudonense, e el obispo iva con ellos. E en aqul logar avía un omne que era demoniado, e por la su fuerça de aquel mal, [el] omne quemó una grant partida de la cibdat. E quando esto vio sant Antolín tornose contra el pueblo e mandoles facer oración, e luego mano a mano fue muerto el fuego e fueron librados de aquel peligro.

E salió dende e fuese sant Antolín para una cibdat que avía nonbre Brenense e allegose a un sancto que dicían Lino $^{50}$, e predicó a estos omnes e convertió muchos dellos a la fe de Jhesu Christo.

E después salió dende e fue a predicar a un logar que deçían Val Noble. E era señor de aquella tierra un rey que

49 “E así como la Cruz es dicha blago, e el blago es fecho en semejança de cayado de pastor, por ende los prelados de Sancta Eglesia, que son dichos «pastores», traen los blagos en las manos, que son dichas «troças», e lievan ante sí el pueblo, que es so su guarda. Ca manera es de todo pastor bueno que se para sienpre en logar alto e tiene la cayada en la mano, por que toda vía vea a ojo las ovejas e vea al lobo si viene a ellas, e lo pueda espantar con aquella cayada por que non llegue a ellas". Anónimo, Un sermonario castellano medieval, 1400-1500.

50 “E los papas, sus susçessores, asi mesmo fueron martirizados ca, despues que sant Pedro fue colgado por los pies, por mandado del enperador Nero, sennor sant Lino papa ovo cortada la cabeça en Roma". Antón de Zorita, Árbol de batallas, de Honoré Bouvet, ca. 1440-1460. 
70 decían Festo. E sant Antolín predicolo e tornolo a la fe de Jhesu Christo. E este rey tomó grant amor de sant Antolín e diole un logar apartado para que ficiese su oración. E sant Antolín fiço y una eglicia e duró ý él un tienpo. [fol. CCXLIId] E después díxole que quería ir para otras tierras.

75 E esa ora pesó mucho al rey, mas non pudo al facer e rogole que viniese ver lo más aína que pudiese.

E sant Antolín fuese a otro logar, e el rey Theodorico, su tío, como lo vio predicar pesole mucho del mal que le avía fecho e saliole a rescibir con grant onra. E siguiole mucho que visquiese ${ }^{51}$ con él, que le quería facer obispo ya que él v[e]ía que tanta era la su santidat. E sant Antolín non quiso rescibir ninguna dignidat, temiendo que non podría servir a Dios tan bien como en aquel servicio en que él andava predicando. E essa ora los privados del rey, quando vieron que el rey tanto [fue irado] ${ }^{52}$ amor avía con él, bolviéronle otra vez con él. E el rey creyolo todo quanto le dixieron e tanto fue irado contra él que le mandó echar en la carcel e mandole meter en cadenas e defendió que le non diesen de comer nin de bever.

90 E así estando en la cárcel el Nuestro Señor Dios enbiole el ángel que le tornase en la cárcel, e estudo con él siete días que le non fiço mengua de comer nin bever. E acabo de siete días enbió Nuestro [fol. CCXLIIIa] Señor la gracia de Sancti Spiritus sobre un fijo de un omne que decían 95 Patricio, e al fijo decían Almachio, e dávale de comer lo que avía menester e ayudávale a sotener las cadenas. E el

51 “E llegando en Italia e oviendo voluntad de fazer allí alguna puebla en que visquiese, (e) fízola donde agora es Roma, donde feneçió sus días e trabajos e vida, sopiendo por graçia debina cómo allí avía de ser cabeça de la Iglesia de Dios". Lope García de Salazar, Istoria de las bienandanzas e fortunas, ca. 1471-1476.

52 Estas palabras son marcadas como erróneas, con una línea horizontal y puntos debajo de las letras. 
rey en este comedio anidó que serie muerto de sed, e de fanbre e del peso de las cadenas. E fuelo a ver a la cárcel e falló allá aquel moço, Almachio, que le sostenía el peso

100 de las cadenas e fue mucho irado e mandole despeñar. E el Nuestro Señor Dios, que nunca quiso desanparar a los que andan en su servicio, ellos coidavan que le dexavan muerto e vino el ángel e diole sano e salvo al rey. E otrosí el rey Theodorico comesciole ${ }^{\text {sic }}$ grant priesa e ovo de ir a 105 una cibdat que decían Penteona; e el moço Almachio, que cuidava que le dexava muerto, fabló muy fuerte e predicava el nonbre de Dios e el rey mandole llamar e ovo de venir ante [él]. E preguntole que cómo escapara, que los sus omnes non le dexavan muerto. E el moço díxole así: "Por 110 el bien aventurado sant Antolín, e por el ángel de Dios que [fol. CCXLIIIb] guardava a él e a mí, escape". E aún dixo el moço: "Aún venga a tienpo que el Nuestro Señor Dios vengue las penas que tu has dadas a sant Antolín. E sepas por cierto que en una facienda as de entrar tú e tu gente e 115 avedes a tomar la muerte en ella". E esa ora el rey fíçose maravillado de lo que le decía. E luego a pocos de días fue todo esto conplido. E el rey Theodorico ovo a atacar una hueste e fue a una isla que decían Mangolenuos contra el rey Pepino a pelear con él. E lidiando fue el rey vencido e 120 allí murió el rey e toda su gente así como lo avía el moço profetiçado.

E el rey Galafio, quando oyó decir que era muerto el rey Theodorico, plogole de coraçón que él quería ver a sant Antolín. E fue a él a la cárcel e falagole e prometiole 125 mucho algo porque dexase la creencia de Dios e adorase los ídolos. E sant Antolín tovose con Dios e despreció todas aquellas palabras que le decían. E essa ora el rey Galafio fue mucho irado e mandole dar muchas penas. E otros que estavan ý aquella ora, christianos [fol. CCXLIIIc] por 130 las predicaçiones que avían oídas, acometiéronse a la fe de Jhesu Christo e otrosí mandoles dar el rey muchas penas 
e mandoles echar en la cárcel. E sant Antolín predicávales todavía que despreciasen los ídolos e que creyesen en Dios. E esa ora vino el ángel de Dios e soltolos a todos 135 de la cárcel. E viéndolo los que los guardavan tan grant miraglo, ovieron consejo en uno e torrnáronse christianos. E estas nuevas sonaron al rey Galafio e el rey mandolos a todos degollar e que guardasen a sant Antolín.

E después fiço meter a sant Antolín en una olla de pie140 dra sufre, las manos e los pies atados, e dieron fuego deyuso a la olla fasta que fervía, e sant Antolín fincó sano que le non fiço ningunt mal. E los que metían la leña deyuso de la olla, quando vieron a tal miraglo, luego se tornaron christianos. E sant Antolín bendixo aquel plomo e aquella 145 piedra sufre e ello tornose semejança de agua. E él yaciendo en la olla, tomávalo con la mano e echávalo sobre todos e dávales bautismo [fol. CCXLIIId] e todos creyeron firmemente en Jhesu Christo. E tantas fueron de las gentes allegadas a aver ${ }^{\text {sic }}$ este miraglo, que de la espesedunbre ${ }^{53}$ que 150 era entrellos murió un moço fijo de una viuda. E su madre, con grant $\operatorname{coyta}^{54}$ que tenía por él, fuese para sant Antolín e él ovo duelo della; e rogó a Nuestro Señor los finojos fincados e la oración acabada levantose el moço sano e guarido. E el moço començó a alabar el nonbre de Jhesu Christo, e

53 “E la sangre más gruesa, en la sustançia natural quemada de la mucha calor, faze apostema: fázese quando el omne abonda sangre gruesa \& se baña después del fenchimiento de los gouierrnos \& trabajo, asý que la sangre es mouida a las partes de fuera \&, por su groseza \& dureza, non puede ser rresoluida del calor; \& rremanesçiente, en el cuero faze apostema, cuya señal es fuerte dureza (por la espesedunbre de la sangre \& por el fenchimiento del lugar), bermejor fosca (por la calor de la materia), ençendimiento (por el quemamiento)". Anónimo, Traducción de la Cirugía Mayor de Lanfranco, 1495.

54 «Vidi afliccionem populi mei in Egipto et clamorem eius»; 'vi -dize el Señorla coyta e lloro del mi pueblo en Egipto e ove piedat dél”. Anónimo, Sermones de la Real Colegiata de San Isidoro de León, ca. 1500. 
155 dixo una voz alta: “ $¡ Y$ Yo vi a[1 $]^{55}$ tu Señor Jhesu Christo que decía a los ángeles que tornasen el ánima deste moço al cuerpo por el ruego de sant Antolín!". E las gentes que allí estavan quando esto oyeron, dixeron: " $¡$ Verdaderamente non ay otro Dios sino este que predica sant Antolín!". E 160 esa ora creyeron en él e ficieronse bautiçar.

E quando lo vio el rey Galafio, fiço ayuntar los sabios todos del tenplo e fueron a sant Antolín, e prometiéronle muchos de algos e falagáronle quanto pudieron que dexase la ley de Christo e que adorase los ídolos. E sant Antolín 165 tomose a departir con ellos, e todos sus dichos e falagos preciolos poco. E quando vieron que le [fol. CCXLIVa] non podían mover por ninguna manera, començaron a desmayar e dixieron entresí: "Éste ha de ser nuestro mayoral en la virtud del Spíritu Sancto que es con él".

$170 \quad$ E essa ora quando vio el rey que non se osavan tomar con él quando vio que ivan restañando ${ }^{56}$, tomó una muela con una grant cadena e fíçola echar al cuello de sant Antolín e despeñole en un lago que deçían Garona ${ }^{57}$. Mas él por la virtud de Dios andudo con la muela quatro días 175 sobre el agua e sant Antolín encima de la muela. E quando lo vieron los que le despeñaron, metiéronse en el agua e demandáronle perdonase, e essa ora ficieronse bautiçar e

55 En el manuscrito: la.

56 El dulce y docto contender cantando / de Alfeo y de Damón, que embevecida / la novilla admiró, casi olvidando / la yerva y el pacer, por quien perdida / la presa tuvo el lince, y restañando / los ríos sossegaron su corrida. Fray Luis de León, Traducciones clásicas, ca. 1550-1580. (Este es el registro más próximo al siglo XV que registra el Corpus Diacrónico del Español).

57 “Es tierra silvestre \& montuosa \& llena de montañas y en muchos lugares ha muchas viñas, tanto que a sus vezinos \& a las islas del mar provee, y es separada de la provinçia de Tholosa por el rio de Garona, el qual pasando por ella viene fasta Burdeos, prinçipal villa \& metropolitana de Gascoña y ende entra en el mar, segund dize Isidoro en el libro .ix. en el capitulo de los vocablos de las gentes." Fray Vicente de Burgos, Traducción de El Libro de Propietatibus Rerum de Bartolomé Anglicus, 1494. 
tornáronse a la fe de Nuestro Señor Jhesu Christo.

E luego, por la virtud de Dios, sant Antolín salió de 180 aquel logar e fue predicar a muchos logares. E después tornose a Pamia, donde era natural. E falló a aquel moço, Almachio, e contole quantas cosas avía pasado e sofridas por amor de Jhesu Christo. E estudieron ${ }^{58}$ amos en un logar, e en aquel logar avía una fuente oriental e allí servían 185 a Dios.

E un día un rey, [fol. CCXLIVb] que decían Metapio, enbió sus gentes atacar e fallaron a sant Antolín e Almachio en oración, que estavan a la fuente oriental. Uno que decían Iohan preste, de que vio a sant Antolín e Almachio, 190 dixo que con tales como aquéllos avía de rescibir martirio. E luego este Juan preste fuese para sant Antolín, e ellos estando ý vinieron los cavalleros del rey Metapio que estavan asechando, e prendiéronlos e enbiáronlos al rey. E el rey desí los vio, díxoles:

$195-$ - ¿Vós sodes aquellos encantadores que encantades los omnes por vuestras predicaçiones oír? ¡Seredes en la cárcel metidos, quitat vós de la mala profía e adorar los ídolos e facet los mandamientos de los rreyes!

E respondiole sant Antolín, e díxole:

$200-$ Nos non somos encantadores, mas guardadores de las ánimas para Jhesu Christo, en cuyo servicio andamos.

E quando vio el rey que por ninguna manera non los podía tornar, fíçolos traer a la ribera de un río que es llamado Arreja, que corre acerca de un castillo que ha nonbre

205 Pamia, e allí le cortaron la cabesça con el braço diestro a sant Antolín, e a Almachio e a Juan [fol. CCXLIVc] preste. E esto fue por mandado del rrey Metapio.

58 "Ca el Abadia do tan grand yra \& dolor nos es venjda yo vos prometo de la hazer mucho mejor \& mas conplida que antes era \& mas de monges pondre dentro que jamas ende estudieron". Anónimo, Historia de la linda Melosina, 1489. 
E una dueña mora nieta del rey Metapio, por desonra de sant Antolín e porque los christianos non fallasen los 210 sus cuerpos, fiço echar el su cuerpo de sant Antolín e de los otros en aquel río que decían Arregia; mas por la piedat de Dios que quiere a los suyos guardar e vengar, aquel río non corrío por aquel logar, mas de allí adelante tomó un atajo por otro logar. E aquel castillo que decían Pamia,

215 luego que non corrió aquel río acerca dél, oviéronle a tomar los christianos, que era ante de moros. E fallaron los cuerpos sanctos todos tres e condesáronlos para reliquias.

Este miraglo e otros muchos fiço Dios por amor de sant Antolín. E la sangre que cayera dellos en el río, por la vir220 tud de Dios, toda se allegó a los cuerpos dellos que ninguna gota non se perdió. E la cabeça de sant Antolín que fue echada en aquel río con el braço diestro que era perdido, truxiéronlo los ángeles en una navera por aquel río de Arregia; e entró en otro río que decían Garona, e entró 225 en otro río que decían [fol. CCXLIVd] Tramensi de Tranç, e entró en otro río que deçían Unarión. E estos quatro ríos aviendo pasados, por la gracia de Dios, ivan dos ángeles por los aires en semejança de dos aguilas blancas que guiavan la cabeça con el braço, e leváronla sobre aquellos ríos 230 fasta un logar que decían Val Noble, do morava el rey Festo que avía convertido san Antolín. E quando esto vio el rey fue mucho maravillado ensí e entendió que por Spíritu Sancto viniera aquello. E después que el vio la navera e la cabeça e el braço de sant Antolín, dixo a sus conpañeros:

235 “ ¡Vedes quánta es la gracia de Dios! ¡Éste quando era bivo a mí demandó morada e agora es con Dios en el cielo coronado!”. E dixo: “¡Éste me prometió en su vida que vernía ver e non pudo en la vida! ¡E agora él muerto quísolo Dios complir por él de me venir ver!". E essa ora aquel rey Festo 240 tomó aquellas reliquias de sant Antolín e fiço una eglicia muy noble a onor e onra de sant Antolín. E enterró ý la cabesça con el braço e el cuerpo otrosí con el costado. 
E Almachio e Juan el preste, que murieron en aquel río [fol. CCXLVa] que decían Arregia, la sangre que salió 245 dellos cayose en las ondas del río. E tomaron las mugeres aquellos dos cuerpos e enterráronlos cabe un logar aína de Vuenafuente que decían oriental. E estudieron allí grant tienpo que lo non sopo omne en el mundo, del cuerpo de sant Antolín, nin de los cuerpos destos mártires que mu250 rieron con él.

E este fue muy grant miraglo: ${ }^{59}$ una buena dueña avía muchas vacas e echolas al monte a pascer, e en aquel monte avía grant montaña de árboles. E un toro de los de aquellas vacas, apartávase de las vacas e salía por una senda e

255 iva a aquel logar do yacía sant Antolín e aquellos cuerpos, e lamía la piedra do yacía enterrado sant Antolín e a la noche tornávase para las vacas. E las vacas andavan magras e el toro gruesso. E esa ora dixo el pastor que non sabía dó se ivan, pero díxole que cada día iva el toro por una senda 260 e se apartava de las vacas todo el día, e después a la noche, que se torrnava a ellas. E esa ora mandó la dueña que viese e guardase aquel logar fasta do iva e a do [fol. CCXLVb] llegava e que gelo dixiese. E el pastor fíçolo así e aguardolo e fallolo lamiendo en aquella piedra do yacía el cuerpo

265 de sant Antolín, e tornó para la buena dueña e díxogelo. E entendió que por Spíritu Sancto venía e asmó entresí que algunos cuerpos sanctos yacían allí. E la buena dueña ayuntó clérigos quantos pudo aver e llamó a buenos omnes e fueron a aquel logar e fallaron el cuerpo de sant

270 Antolín e los otros. E tomáronlos con muy grant alegría e leváronlos a la eglicia de sant Martín, que era edificada en la ribera de aquel río que decían Arregia. E enterráronlos cabe el altar. E en aquel logar face Dios muchos miraglos por el amor de sant Antolín e destos mártires. 
275 E desto que avemos dicho face la eglicia una vegada reverencia en el año quando murió, que cae un día andado del mes de setienbre; e fácele otra vegada reverencia por este tienpo que fue el su cuerpo trasladado de aquel logar do yacía a la fuente oriental, en la Corona, en la eglicia de 280 sant Martín así como agora oýstes decir.

E así face la eglicia dos veces fiesta en el año dél porque es buena fiesta.

Marcos Cortés Guadarrama

UniVERSIDAd Veracruzana 